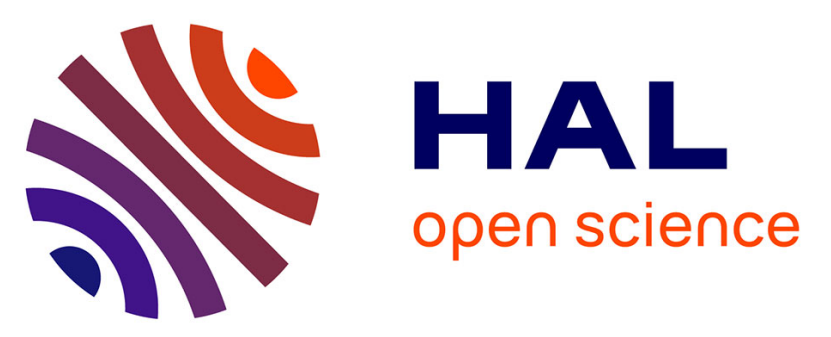

\title{
Interspecific hybridisation and interaction with cultivars affect the genetic variation of Ulmus minor and Ulmus glabra in Flanders
}

K. Cox, A. Vanden Broeck, K. Vander Mijnsbrugge, J. Buiteveld, E. Collin, H.M. Heybroek, J. Mergeay

\section{To cite this version:}

K. Cox, A. Vanden Broeck, K. Vander Mijnsbrugge, J. Buiteveld, E. Collin, et al.. Interspecific hybridisation and interaction with cultivars affect the genetic variation of Ulmus minor and Ulmus glabra in Flanders. Tree Genetics and Genomes, 2014, 10 (4), pp.813-826. 10.1007/s11295-014-07224. hal-02499791

\section{HAL Id: hal-02499791 \\ https://hal.science/hal-02499791}

Submitted on 5 Mar 2020

HAL is a multi-disciplinary open access archive for the deposit and dissemination of scientific research documents, whether they are published or not. The documents may come from teaching and research institutions in France or abroad, or from public or private research centers.
L'archive ouverte pluridisciplinaire HAL, est destinée au dépôt et à la diffusion de documents scientifiques de niveau recherche, publiés ou non, émanant des établissements d'enseignement et de recherche français ou étrangers, des laboratoires publics ou privés. 
r-produced version of the article published in: Tree genetics and genomes, 2014 vol $10, n^{\circ} 4$, p. $813-826$

The original publication is available at: http://link.springer.com/ or at http://link.live.springer.com/article/10.1007/s11295-014-0722-4 DOI 10.1007/s11295-014-0722-4

1

\section{Interspecific hybridisation and interaction with cultivars affect the genetic variation of} Ulmus minor and $U$. glabra in Flanders

Karen Cox $^{1}$, An Vanden Broeck ${ }^{1}$, Kristine Vander Mijnsbrugge ${ }^{1}$, Joukje Buiteveld ${ }^{2}$, Eric Collin ${ }^{3}$, Hans M. Heybroek ${ }^{4}$ and Joachim Mergeay ${ }^{1}$

(1) Research Institute for Nature and Forest, Gaverstraat 4, B-9500 Geraardsbergen, Belgium

(2) Centre for Genetic Resources, the Netherlands (CGN), PO box 47, 6700AA WAGENINGEN, the Netherlands

(3) Irstea, UR EFNO, centre de Nogent-sur-Vernisson, F-45290 Nogent-sur-Vernisson, France

(4) since 1992 retired from the Dorschkamp Forest Research Station, Wageningen; Jonkerlaan 90-113, 2242 EX Wassenaar, the Netherlands

Corresponding author: Karen Cox; tel.: +32 5461 88; fax: +32 5461 60; E-mail: karen.cox@inbo.be 
1 Abstract

2 Interspecific hybridisation and gene flow from cultivated plants may have profound effects on the 3 evolution of wild species. Considering the cultural history and past use of $U$. minor and $U$. glabra trees 4 in Flanders (northern Belgium), we investigated the extent of human impact on the genetic variation of 5 the remaining, supposedly indigenous elm populations. We therefore examined the rate of 6 interspecific hybridisation, which is expected to be higher under human influence, the occurrence of 7 clones within and among locations, the presence of cultivars and their possible offspring. Based on 8 results produced using 385 Amplified Fragment Length Polymorphic (AFLP) markers, 46\% of the 106 9 investigated Flemish elms appeared to be $\mathrm{F} 1$ hybrids or backcrosses to one of the parent species, 10 while no F2 hybrids (F1 x F1 progeny) were found. Clonality was mainly found among U. minor and 11 hybrids, which are more likely to form root suckers or sprouts as opposed to U. glabra. The majority of 12 the studied locations ( $76 \%$ of the locations with multiple samples) showed evidence of clonal 13 reproduction. Several, sometimes distant, locations shared a multilocus lineage. We also found 14 indications of gene flow from cultivated elms into native species. It is conceivable that reproductive 15 material has been moved around extensively, obscuring the natural genetic structure of the elm 16 populations. The results help guide the Flemish elm genetic resources conservation program.

17 Key words: Ulmus minor, Ulmus glabra, hybridisation, elm cultivars, clonal reproduction, human18 mediated disturbance 
Ulmus minor Mill. (Field elm) and U. glabra Huds. (Wych elm) are native deciduous trees in western

3 Europe. Especially U. minor and U. x hollandica (i.e. the hybrid between U. minor and U. glabra) have been widely planted over the ages, in the cities as well as in the countryside, on roadsides and along property borders, in hedges, near manors and farmsteads, as standards as well as coppice. Planting stock was sometimes obtained from relatively distant provenances (Heybroek et al. 2009). In a forest in The Hague (the Netherlands), for example, elms from Flanders (northern Belgium) and Utrecht (the Netherlands) were planted in the $16^{\text {th }}$ century (van Dissel 1912). Richens (1983) speculated that even prehistoric tribes carried live elms on their wanderings. But typically local material from surrounding forests, seedlings or root suckers, would have been used for plantings. Elm timber was greatly appreciated for many purposes, e.g. coppice produced firewood and pliable twigs. Consequently, elms have a long history of cultivation. Local cultivars were known since the 17th century and probably earlier. In the Mediterranean, but also in areas in western Europe where the Romans introduced their viticulture, elms were raised to act as vine supports, while the elm leaves served as an excellent fodder for cows and sheep (Forster and Heffner 1954; Fuentes-Utrilla et al. 2004). For this purpose, they brought a special cultivar, the 'Atinia' (Gil et al. 2004). More recent cultivars are often non-European elms or hybrids between European and non-European elms, such as $U$. wallichiana Planch. (Himalayan elm), U. japonica (Rehder) Sarg. (or U. davidiana var. japonica (Rheder) Nakai; Japanese elm) and U. pumila L. (Siberian elm).

In addition to habitat loss and fragmentation due to changes in land use, the Dutch Elm Disease (DED) severely reduced the number of elm trees starting from around 1910. DED is caused by the non-native fungi, Ophiostoma ulmi (Buisman) Nannf. and O. novo-ulmi Brasier, which are spread by bark beetles of Scolytus Geoffroy (Coleoptera, Scolitidae; Brasier 2001). The main vectors in western Europe are S. scolytus and S. multistriatus (Webber 2004). Considering the severe threats European elms are under, national actions were taken to conserve the remaining germplasm. In turn, this has led to the initiative within the European Forest Genetic Resources (EUFORGEN) cooperative program to realise a conservation plan on a European level (Collin 2002). Furthermore, an EU project on the "Co-ordination for conservation, characterisation, collection and utilisation of genetic resources of European elms" ran from 1997 till 2001 (RESGEN CT96-78). In Flanders, our study area, new clones of native elms are still being added to the ex situ collections, initiated within the RESGEN project. Still, limited knowledge is available on the level of genetic variation residing in elm populations and to what extent this was influenced by human activities.

$U$. minor and $U$. glabra co-occur in Flanders, but are also able to hybridise with each other $(U . x$ hollandica Mill.), making their taxonomy extremely difficult (Goodall-Copestake et al. 2005). Although hybridisation between $U$. minor and $U$. glabra is a natural process, it can also be human-mediated, through habitat modification, species introduction or translocation. Human activities can therefore encourage hybridisation (Ellstrand and Schierenbeck 2000; Rhymer and Simberloff 1996). For example, $U$. pumila was introduced in Spain and Italy. Its hybrid with the native $U$. minor is now common in both countries (Brunet et al. 2013; Cogolludo-Agustin et al. 2000). Natural interspecific 
hybridisation as well as gene flow from cultivated elms to their native relatives are processes with significant evolutionary consequences. A potential concern is outbreeding depression when coadapted gene-complexes are broken up, causing a decrease in fitness (Eucalyptus spp.: Potts et al. 2003; Edmands 2007; Laikre et al. 2010; Lynch 1991). Also, asymmetric gene flow could occur when one species is less abundant than the other, with females of the rare species receiving a high amount of heterospecific pollen, causing a higher risk of mate recognition errors (Mayr 1963; Wirtz 1999). Moreover, first generation backcrossing will more likely happen with the more common species, leading to asymmetric introgression (Rieseberg 1997). For instance, species abundance influenced the direction of introgression in oak populations (Lepais et al. 2009) as well as between two Morus spp. (Burgess et al. 2005). Interspecific hybridisation may, however, also result in the addition of genetic variability that facilitates habitat expansion (Arnold 1997). Conversely, the commercial release of cultivated trees (or cultivars) can result in homogenisation of the genetic composition and structure of the wild populations through introgression. These genetic risks are of particular concern when the planted trees represent a narrow gene pool spread on a wide scale and the related wild species is highly threatened by habitat reduction or diseases (e.g. Populus spp.: Santos-del-Blanco et al. 2013; Vanden-Broeck et al. 2012; Smulders et al. 2008; Malus spp.: Kron and Husband 2009; Coffea arabica: Aerts et al. 2013; Prunus avium: Mariette et al. 2010).

Considering the cultural history and past use of $U$. minor and U. glabra trees in Flanders, we investigated if the genetic variation of the remaining, supposedly indigenous elm populations is influenced by human activities. The answer to this research question could help guide the Flemish elm genetic resources conservation program. We therefore examined 1) the rate of interspecific hybridisation, which is expected to be elevated due to human activities, 2) the occurrence of ramets (i.e. genetically identical individuals originating vegetatively from a single ancestor) within and among locations and 3) the presence of cultivars and their offspring in Flemish indigenous elm populations.

\section{Material and methods}

Samples and DNA extraction

Three sets of samples were used in this study. Between 2007 and 2009 leaves of adult Ulmus minor, $U$. glabra trees and their hybrids were collected in Flanders in northern Belgium for the first set (Table 1, Fig. 1). The leaves were collected in a gene bank containing ramets of the original trees (i.e. ortets) except for the samples in the location coded BESP (Table 1). The indigenous ortets were at least $3 \mathrm{~m}$ apart from each other to diminish the risk of sampling ramets. The census number of elm trees was lower than 30, except at location BERI $(n>50)$ (Table 1). We limited the number of samples per location to address the research questions on the regional scale (i.e. Flanders). The species of the elm trees was identified morphologically according to Lambinon et al. (1998). This set of samples ('dataset 1 ') entails the focus of our study and is therefore used in every analysis.

The second set ('dataset 2') comprises samples of Ulmus minor and U. glabra, which are used as references for these three pure species in the hybrid detection analyses (Table 1). They were 
superscript in Table 1). They are originally from Belgium (location BETO), France, Italy, Germany and

2 Greece, and were collected mainly in forests and screened genetically by Goodall-Copestake et al.

3 (2005). Also, a few samples from six localities in France were added (locations FRAU, FRCB, FRLR,

4 FRLV, FRSP and FRBL), as well as one sample of $U$. procera Salisb. (English or Atinian elm)

5 collected in Kallstadt, Germany.

6 The third set of samples ('dataset 3') contains cultivars which were mainly collected in the 7 Netherlands, except for 'Klemmer', which was provided by Irstea (France) and originated from

8 Wakehurst Place (UK) (Table 2). The Dutch locations of elm cultivars are well known by Heybroek et 9 al. (2009); several recent cultivars in this study were even selected and released by $\mathrm{H}$. Heybroek. 10 Some of the cultivars are hybrids with $U$. wallichiana, $U$. japonica or $U$. pumila. The cultivars were included in clone and parentage analyses to investigate their influence on supposedly indigenous individuals of $U$. minor, $U$. glabra and their interspecific hybrids. Well-known cultivars 'C. Buisman' (U. minor), 'Sarniensis' (U. minor) and 'Horizontalis' (U. glabra) were also used as reference samples representing pure $U$. minor and $U$. glabra in hybrid detection analyses.

The leaves were stored on silica gel. Total DNA was extracted from ground leaf samples, partly with QuickPick $^{\text {TM }}$ SML Plant DNA purification kit in combination with the PickPen 8-M magnectic tool or the MagRo 8-M robotic workstation (Isogen Life Science) on $5 \mathrm{mg}$ of dried leaf tissue, and partly with DNeasy Plant Mini Kit (Qiagen) on 20 mg of dried leaf tissue. The integrity of the DNA was assessed on $1.5 \%$ agarose gels, and the purity and concentration with the ND-1000 Nano-Drop spectrophotometer (NanoDrop Technologies).

AFLP analysis

Amplified Fragment Length Polymorphism (AFLP) fingerprints were generated according to Vos et al. (1995), but with restriction and ligation conducted in one single step. Initially, 21 primer combinations (EcoRI/Msel) were tested on 16 samples (14 individuals and 2 replicates). The following two primer combinations were selected for the selective amplifications: EcoRI-AGC(ned)/Msel-CTG and EcoRIACC(ned)/Msel-CTG. We used the RawGeno v 2.0 R CRAN package (Arrigo et al. 2009) for automated scoring, which resulted in 385 polymorphic loci.

There were seven samples with poor quality AFLP electropherograms for one or both primer combinations. To avoid series of missing values, we discarded these samples from further analysis, leaving a total of 177 samples of which 34 (19\%) were randomly replicated to assess reproducibility. Mean typing error reached 4\% (following Bonin et al. 2004) and mean Dice similarity between pairs of replicates was 0.95. The polymorphism information content (PIC) of each locus was calculated (Anderson et al. 1993).

Data analysis

The hybrid detection analysis and the sibship analysis were executed under the assumption of unlinked markers (see below). We therefore assessed linkage disequilibrium (LD) among AFLP loci 
by performing logistic regressions between pairs of loci (e.g. Poncet et al. 2010). To correct for multiple testing, we used the false discovery rate approach (FDR; Benjamini and Hochberg 1995) with

3 R package brainwaver (Achard 2012). The maximum FDR was set at 5\%. Computations were done with the statistical software platform $R$ version 2.15 (R Development Core Team 2010). Another method to detect linkage disequilibrium by Haubold et al. (1998) was used, implemented in LIAN 3.6 (Haubold and Hudson 2000). The standardized index of association $\left(\mathrm{I}_{\mathrm{A}}^{\mathrm{S}}\right)$ was calculated, based on 10,000 permutations. Values for dataset 1, with 309 polymorphic markers, were produced, as well as 8 for three subsets of dataset 1: U. glabra samples (199 polymorphic markers), U. minor samples (183 polymorphic markers) and their hybrids (232 polymorphic markers). This subdivision was based on the results of the hybrid detection analyses. It is expected that $U$. minor and the hybrids will show higher LD because of their ability to reproduce asexually. The subsets of dataset 1 were reanalysed with duplicate ramets excluded, resulting in 197 polymorphic markers for the U. glabra samples, 172 for U. minor and 222 for hybrid samples. Recent hybridization between taxa derived from two gene pools with different allele frequencies, should exhibit strong LD. Still, associations among loosely linked markers decay rapidly with subsequent generations of hybrids, resulting in a reduced level of LD (Goodman et al. 1999).

Hybrid identification

In order to investigate the actual extent of interspecific hybridisation among Flemish elms, we used the Bayesian method implemented in BAPS v 5.4 (Corander et al. 2008). An admixture analysis based on pre-defined groups was performed using 100 iterations. We restricted the analyses to samples identified as $U$. minor, U. glabra and their hybrids of all three datasets (i.e. 164 samples of 182). The samples screened genetically by Goodall-Copestake et al. (2005), were used as reference samples for $U$. minor and U. glabra (i.e. of the second dataset and the sample of location BETO from dataset 1). Also the well-known cultivars 'C. Buisman' (U. minor), 'Sarniensis' (U. minor) and 'Horizontalis' ( $U$. glabra) were treated as reference samples for both pure species. Individuals with admixture values $\left(q_{i}\right) \geq 0.90$ for either of the two groups were assigned to purebreds. In other cases they were considered to be admixed (Vähä and Primmer 2006).

Another Bayesian approach, NewHybrids v1.1b3 (Anderson and Thompson 2002), was used on the same dataset. The program was run with the default parameters for the six genotype class frequencies (pure U. minor, pure U. glabra, F1 hybrids and F2 progeny (of F1 hybrid parents) and backcrossed F1 hybrids), uniform priors and two runs with a burn-in phase of 10,000 steps and 100,000 MCMC iterations. The same reference samples as in BAPS were used to represent the pure species. The samples used as priors were specified as sampled separately from the rest of the mixture of interest, except the sample of BETO located in Flanders. Individuals were considered to belong to one of the predefined classes if $P \geq 0.90$ for that genotypic class (Vähä and Primmer 2006). markers in the dataset are unlinked (Anderson 2008), which also applies for the BAPS analysis. Although we found significant LD among loci of the Flemish samples (see results), this concerned only a very small number of loci. 
2 Ramets (or clone mates) belonging to the same clonal lineage bear the same multilocus genotype or, 3 if somatic mutations have occurred, the same multilocus lineage (MLL). To identify MLLs among the 4 samples, we used GenoType (Meirmans and Van Tienderen 2004) on the three datasets combined. First, the discriminative power of the AFLP markers was assessed by plotting the number of loci versus genotypic richness (G:N; i.e. the ratio of the number of MLLs and number of samples) for an increasing number of loci. For the calculations of genotypic richness we first used a set of two highly informative markers successively adding sets of 16 markers with decreasing information content, resulting in calculations based on two, 18, 34, 50, 66, etc. markers, respectively. For each set of markers, the number of MLLs was obtained using several thresholds, ranging from 0.90 to 0.99 Dice similarity, to account for differences in actual thresholds between different sets of loci. When genotypic richness reaches a plateau, the markers are considered to possess enough resolution to reliably assign clonal lineages (Arnaud-Haond et al. 2005). The Dice similarity index was used as a distance measure between all pairs of individuals. As scoring errors and mutations can cause a genetic distance between members of the same MLL to be higher than zero, a threshold needs to be chosen to account for these differences, which are indicated by a multimodal frequency distribution of genetic distances (Arnaud-Haond et al. 2005; Douhovnikoff and Dodd 2003; Meirmans and Van Tienderen 2004). Consequently, the frequency distribution of the distances and the mean Dice similarity of the pairs of replicated samples were used to define an appropriate threshold.

Whether members of a MLL were the result of sexual reproduction, was evaluated through the clonal population structure test implemented in GENODIVE v2.0b17 (Meirmans and Van Tienderen 2004). Here, the observed clonal diversity is compared with the diversity achieved by randomising alleles over individuals (1,000 permutations). Clonal diversity is expected to be lower under clonal reproduction than under sexual reproduction (Gómez and Carvalho 2000). This test includes the threshold used for assigning MLLs. Nei's corrected diversity index (Nei 1978) was used as test statistic and the alleles were randomised over all individuals of the Flemish region (i.e. dataset 1 ). The same calculations were performed for the Flemish U. minor, U. glaba and hybrid trees separately. It should be noted that similar genotypes could also be the result of selfing, biparental inbreeding and population genetic structure (Halkett et al. 2005).

\section{Parentage and sibship analysis}

To evaluate past or present influence of elm cultivars on the putative indigenous elm populations of Flanders, we conducted a sibship and parentage analysis with Colony v2.0.1.9 (Jones and Wang 2009). In this program, a maximum likelihood method is used. Offspring are clustered into paternal and maternal families using a simulated annealing approach to maximise the group likelihood value. Then, candidate parents are assigned to the clusters at a $95 \%$ confidence level. If no candidate parents seem available, the program reconstructs parental genotypes. It can also deal with scoring errors. We excluded monomorphic loci, resulting in a set of 355 polymorphic markers. The offspring dataset contained unique ramets of dataset 1 , while the cultivars of dataset 3 were set as the potential parents, considering their release dates are often quite old $\left(18^{\text {th }}-\right.$ early $19^{\text {th }}$ century) and/or their 
widespread use, especially of 'Belgica', 'Major', 'Klemmer' and 'Vegeta'. The more recent cultivars, mostly parented by non-native elms, were included as 'negative controls' in the candidate parents set. We found some linkage among markers (see results). This could lower the precision of the analysis, but is probably compensated by the high number of informative markers (Wang and Santure 2009). We did not consider tree size or any other measure of tree age in the analysis. Because many trees in our study are part of old hedges, coppice trees or root suckers of trees that succumbed to DED, age estimates are highly unreliable. The results from this parentage and sibship analysis will therefore only highlight close relations, rather than exact parent-offspring relationships.

\section{$9 \quad$ Results}

\section{Marker information and independence}

The AFLP loci are only moderately polymorphic (Table 3), with a comparable mean PIC for U. minor, $U$. glabra and their hybrids (0.17-0.22). However, when considering loci with a band presence between $5 \%$ and $95 \%$, a minimum of 145 loci still remained with a substantially higher mean PIC between 0.26 and 0.30 .

In dataset $1,3.7 \%$ of the pairwise logistic regressions were significant. Although $\mathrm{I}_{\mathrm{A}}^{\mathrm{S}}$ was low $(0.0174)$ it appeared significant $(P<0.0001)$. The proportion of significant logistic regressions decreased when only $U$. minor $(0.6 \%)$ or hybrids $(0.4 \%)$ were considered, while $I_{A}^{S}$ slightly increased $(0.0182$ and 0.0175 with $\mathrm{P}<0.0001$, respectively). Retaining only unique ramets further rendered insignificant logistic regressions for $U$. minor and only one significant pairwise comparison (0.004\%) for hybrids. The $I_{A}^{S}$ value stayed the same for $U$. minor, but decreased to $0.0111(P<0.0001)$ for the hybrid group. For the set of Flemish U. glabra samples, no significant logistic regressions were detected, while $I_{A}^{S}$ stayed significant with even lower values $(0.0064$ and $0.0049(P<0.0001)$, with and without duplicate ramets, respectively).

\section{Hybrid detection}

Out of 106 trees sampled in Flanders, only 28 were assigned as pure $U$. glabra and 29 as pure $U$. minor with $\mathrm{q}_{i}=1$ using BAPS (Fig. 2). Three out of eight samples that were identified as hybrids in the field, appeared to be pure species (one U. glabra and two U. minor). So, 49 (46\%) of the Flemish samples seemed genetically to be hybrids between these two species, of which 38 (78\%) were identified morphologically as a pure species. Most of the samples were assigned with high probabilities using NewHybrids (80\% with $\mathrm{P} \geq 0.90$ ). Eight Flemish samples showed probabilities between 0.80 and 0.90 . Only 12 Flemish samples had maximum probabilities below 0.80 with seven below 0.70 . These individuals with $\mathrm{P}<0.90$ were all classified as hybrids using BAPS, except for two of location BERI and one sample of BEGE. Their maximum probabilities $(0.78<\mathrm{P}<0.89)$ given by NewHybrids also suggested them to be purebreds. Furthermore, two reference samples of $U$. minor in dataset 2, one of FRGS and one of GELD, were classified by NewHybrids as backcrosses to $U$. minor, however with probabilities of 0.52 and 0.55 , respectively. BAPS did not reclassify these reference samples. No F2 hybrids were found, based on the NewHybrids results. As for the cultivars, 
and 'Dampieri' as a cultivar of $U$. minor. Furthermore, both replicates starting from leaf tissue of 'Major' appeared to be pure U. minor, but the cultivar is claimed to be a hybrid. The other cultivars involving solely $U$. minor and/or $U$. glabra and the remaining samples of dataset 2 were assigned to their predetermined group.

For all the following analyses, samples were assigned to the species class given by NewHybrids and BAPS results.

\section{Clonality}

The resolution of the markers appeared high enough to reliably detect clones. The relationship between number of markers and genotypic richness is asymptotic, reaching a plateau at approximately 96 markers (Fig. 3). The frequency distribution of pairwise Dice similarity values was more or less bimodal, with a small peak towards lower distances. Fig. 4 shows this small peak. Although the valley between the first and second peak is considered a probable threshold (Meirmans and Van Tienderen 2004), which is at a Dice similarity of 0.90 , this seemed questionable. At this level of similarity, three French samples of two locations separated by more than $100 \mathrm{~km}$, appeared to be clones. Although this is not impossible through human mediation, this seems a less likely scenario. We therefore resided to select a more conservative threshold of 0.94 Dice similarity, which is slightly lower than the mean Dice similarity of 0.95 calculated for the duplicate samples to account for somatic mutations and which coincides with the first small drop in frequency in Fig. 4. In addition, three ramets of 'Lobel' and two of 'Plantyn', each collected at a different locality, were assigned to the correct MLL at this threshold.

Fig. 2 indicates the identified MLLs with multiple ramets for the Flemish locations. Clones were detected at 12 of the 16 Flemish sampling locations and at four French locations, where more than one tree was sampled. They were mostly found among U. minor and hybrids, mainly with higher admixture levels for $U$. minor genes, but also a few individuals of $U$. glabra appeared to be ramets. Two MLLs with each two ramets of $U$. glabra were detected at location BERI (MLL '9' and '10'; Fig. 2). The $U$. glabra ramets of MLL ' 9 ' are neighbouring trees.

Certain MLLs are present on more than one location (Euclidean distances between locations): MLL 'A' at locations BEDI, BEME2 and BESC (16 to $39 \mathrm{~km}$ ), MLL 'B' at BEDM2 and BEHO (4.5 km), MLL ' $C$ ' at BEEG and BERI (70 km), and MLL 'E' at BEMA and BESC (4.5 km) (Fig. 1). Interestingly, one individual of BEGE and all samples except one of BEME1 belong to the same MLL as the 'Klemmer' cultivar.

Clonal diversity was significantly lower than diversity under random mating for dataset 1 , as well as for each separate species in Flanders $(P<0.001)$.

Also in France, some neighbouring U. minor trees at FRAU, FRLV, FRCB and FRLR, respectively, had a MLL in common. Furthermore, a common MLL was found at locations FRLV and FRAU with a distance of $16 \mathrm{~km}$ between them. 
2 After retaining only unique ramets, dataset 1 contained 64 Flemish samples defined as offspring in the analysis. As expected, no recent cultivars were inferred as parents of our Flemish samples. On the other hand, 'Klemmer', 'Belgica' and 'Major' came up several times as potential parents with high probabilities. These cultivars are at least 130 years old and known to have been widely planted in Flanders. 'Klemmer' was inferred as a parent of a sample of BEGE and of BEME1, where also ramets of 'Klemmer' were found (see the clonality results). 'Major' was found to be a potential parent of individuals at the locations BEOO, BESP, BEEN and BEDI. Additionally, the BEDI location contained another individual, possibly parented by 'Belgica'. This individual is a ramet of MLL ' $A$ ', which was also present in BEME2 and BESC. Furthermore, MLL 'E' found in BEMA and BESC has 'Belgica' as a potential parent. In four (50\%) of these parent-offspring combinations, the admixture proportions of the parents are different from those of the offspring. This suggests that a possible clonal relationship as opposed to a parent-offspring relationship is less likely.

According to the results of Colony, many of the samples were found to be full-sibs or half-sibs (Fig. S1 in Supplementary Material). Only one of 569 pairwise full-sib relationships between individuals (of BEOO and BEEN) had a probability of 0.848 , while other probabilities equalled one. Also, 1 of a total of 89 of inferred pairwise half-sib relationships had a probability of 0.943 and the remaining combinations received the maximum probability value. Location BERI holds many full-sibs of which a few were identified as backcrosses, while the majority seemed to be pure $U$. glabra. Also, a few peculiar full-sib and half-sib combinations could be detected between samples of distant locations, such as BERI, BEGE, BEEG and BEMA. Here, the full-sib relationships are often between potential pure Wych elms and hybrids (F1 or backcrosses to $U$. glabra). The majority of the full-sib combinations between pure $U$. glabra and hybrids, including backcrosses, can possibly be attributed by the uncertainty of the species assignment of several samples using NewHybrids. In fact, $90 \%$ of the 234 full-sib relationships between different species classes, involved samples that were classified as $\mathrm{F} 1$ hybrids or backcrosses to probabilities below 0.90 , of which $50 \%$ was below 0.70 . Taking admixture proportions of these individuals given by BAPS into account, did not change these unlikely combinations. The remaining full-sibs are mainly within particular locations (e.g. BEBR: U. minor) or between locations quite near to each other (e.g. BERI and BETO: U. glabra).

As stated before, because we were not able to estimate the age of the Flemish elms, they could just as well be a mixture of parents and offspring instead of pure offspring, potentially causing full-sib associations between individuals of different admixture classes. In addition, the cultivars assigned as potential parents, may be close relatives but not the parents of the alleged offspring. The results of the sibship analysis are therefore only indicative of family relations.

Discussion

Occurrence of interspecific hybrids 
fertilisation barriers between these two species exist. Former morphological studies already suggested that in Flanders and the Netherlands, the full spectrum of the U. minor-U. glabra complex is present (e.g. Touw 1963). Still, the hybrids do not seem to be recent, since the level of LD appears to be low and advanced generation hybrids are predominant among hybrids (Fig. 2). Because of the high number of hybrids, hybridisation could have been facilitated by human-mediated habitat disturbance (Ellstrand and Schierenbeck 2000; Rhymer and Simberloff 1996). Hybrid clone mates and full-sibs were often found among different locations, indicating human influence through movement of elm planting material and the establishment of cultivars, often hybrids, near natural elm populations (see below).

It seems that F1 elm hybrids are not sterile, judging by the backcrosses that were found. However, F2 offspring of $\mathrm{F} 1$ hybrids were not identified among the sampled trees. A possible reason for failing to detect F2 hybrids, could be an insufficient discriminative power of the AFLP markers, partly because of their dominant character. Still, assignment probabilities to the F2 genotype class never exceeded 0.15. A lack of F2 generations might suggest selection against offspring containing homozygous loci from either species. A loss in fitness might not arise until the second or later hybrid generations because of the increasing severity of homozygous incompatibilities according to the (Bateson)Dobzhansky-Muller model (Turelli and Orr 2000) or because of outbreeding depression (Edmands 2007; Lynch 1991). Zalapa et al. (2009) also did not find second-generation hybrids between $U$. pumila and $U$. rubra. They suggested pollen-stigma incompatibilities between F1 hybrid parents as a possible cause, since F1 hybrids would contain S-alleles from both parents and thus be less likely to crossbreed successfully with another F1 hybrid. On the other hand, Brunet et al. (2013) did find F2 hybrids of $U$. pumila and $U$. minor, which they attributed to the relatively self-compatible nature of $U$. minor, described in the paper of Mittempergher and La Porta (1991). Based on many controlled selfings and crosses between several species and hybrids, including U.minor and U.glabra, Heybroek (1993) detected, however, a high degree of self-incompatibility. Over a period of ten years, producing 24,149 seedlings out of 2,378 pollination bags, 770 crosses and 196 selfings, he found that cross pollination gave 23 times more viable seeds and seedlings than selfing.

Out of 87 samples taken throughout Italy and in some locations in France, Brunet et al. (2013) identified 13 trees (15\%) as F2 with a posterior probability of 0.90 or greater using NewHybrids, or $35 \%$ of the total number of hybrids (37). Bearing in mind these relatively high percentages and our more intensive sampling (i.e. on average the same amount of trees was sampled within a smaller region), missing an $\mathrm{F} 2$ hybrid seems less plausible, unless they are extremely rare.

\section{Natural and artificial clonal propagation}

Evidence of clonality was mostly found among $U$. minor and hybrids with a higher representation of $U$. minor genes. Although clonal reproduction seemed mainly to occur within locations, several ramets of the same MLL were found at different locations in Flanders, with distances of $4.5 \mathrm{~km}$ to more than 60 $\mathrm{km}$. This suggests translocation of elm planting material, preferably root suckers, from one location to the other. Ramets of a genotype in BEHO ( $U$. minor), of MLL ' $C$ ' in BERI and BEEG ( $U$. $x$ hollandica), and of MLL ' 3 ' in BEBR ( $U$. minor) were even detected in the Netherlands using microsatellites (J. 

were found for Populus alba in Sardinia (Brundu et al. 2008) and in Malta (Fussi et al. 2012). Furthermore, many elms in Flanders were found in old hedges (of U. minor; Table 1), indicating past human activity. One of the MLLs identified among the investigated elms appeared to be the cultivar 'Klemmer', confirming human involvement in elm establishment in Flanders. 'Klemmer' originates from Belgium (Ypres) (Elwes et al. 1906). It dates back from 1877 or maybe 1789. It was always rare in the Netherlands and common in Belgium and the north of France in the beginning of the $20^{\text {th }}$ century. However, it is now considered to be rare in general (Heybroek et al. 2009).

As mentioned before, it is difficult to infer an exact threshold to determine which of the samples belong to the same MLL. It seemed highly unlikely that the inferred clone mates resulted from random mating $(P<0.001)$. Even though we cannot entirely rule out the occurrence of selfing, the elm species in question are basically deemed self-incompatible (Heybroek 1993; Nielsen and Kjaer 2010; Townsend 1975). Nearly identical genotypes can also be produced due to extensive inbreeding. Nevertheless, we also found such similar genotypes among distant locations and mainly among $U$. minor and hybrids which can easily be propagated vegetatively using root suckers. We are therefore quite confident about the identified MLLs and the threshold used.

A few samples of U. glabra, of BERI, were detected as ramets of the same MLL. U. glabra is not known to regenerate through sprouting, except on trunks of young trees, nor through root suckering. The two closest clones in BERI could therefore be remnants of an old coppice tree, although no apparent evidence pointing towards this hypothesis was found in the field. Planting, on the other hand, is very plausible as cultivation of the species in Flanders has occurred since the $17^{\text {th }}$ century (Maes 2006). This could also explain the presence of related genotypes of $U$. glabra in BERI, BEGE and BEEG.

Although it is feasible that, within locations, the clones among U. minor and its hybrids with U. glabra were the products of natural clonal reproduction, they could just as well be planted. Even the ortet trees could have originated from another location, most probably from the same region. It is therefore difficult to assess human interference on this level.

Influence of cultivars

Besides the samples with the same MLL as 'Klemmer' found in BEME1 and BEGE, this cultivar could also be the parent of at least two other trees growing in the same locations. Moreover, 'Belgica' and 'Major' were found as potential parents of several sampled trees. Consequently, the three cultivars have influenced the natural elm populations, either through planting and possibly clonal reproduction, and through hybridisation. Like 'Klemmer', cultivars 'Major' and 'Belgica' are old. 'Major' is probably the oldest and dates from around 1600 or even before that (Heybroek et al. 2009). Its origin is uncertain, but seemed to be brought to England in 1689 by Willem III from the Netherlands. It was planted frequently in the Netherlands until 'Belgica' became more popular mid- $19^{\text {th }}$ century. The latter was thought to originate from Belgium in the $18^{\text {th }}$ century, in the Abbey of Dunes with nurseries in Furnes and Bruges (Elwes et al. 1906). It was extensively planted starting from 1850. Almost all elm 
plantings in Belgium and the Netherlands consisted of this cultivar until 1928. In addition, for a long time, 'Belgica' was used as rootstock. Consequently, their age and frequent use in the past make the three cultivars feasible parents of some of the sampled elms. Due to the Flemish origin of at least 'Klemmer' and 'Belgica', with potentially close relatives still present in Flanders, family connections other than parent-offspring relationships are quite possible and should be taken into consideration. An alternative explanation for the assignment of cultivars as parents could be that some elms are in fact ramets of the cultivars in question, suggesting that more somatic mutations have occurred than accounted for by the current threshold for clone assignment. Nonetheless, half of these parentoffspring combinations displayed different admixture levels between parent and offspring, whereas the opposite would be expected among clones.

\section{Consequences for conservation}

Our results suggest high human impact on elm populations obscuring their natural genetic structure. A high number of (advanced generation) hybrids were detected, probably facilitated by human activities such as translocation of trees. This was supported by the ramets found among locations. In addition, cultivar 'Klemmer' was identified among the investigated elms, as well as several individuals showing potential introgression from cultivars 'Major', 'Belgica' and 'Klemmer'.

LD among loci was low but significant and can partly be attributed to clonal reproduction (de Meeûs and Balloux 2004; Tibayrenc et al. 1991). The potential problem of mate or pollen limitation that comes with clonal reproduction could lead to a decrease in fertility or an increase in self-compatibility (Honnay and Jacquemyn 2008; Vallejo-Marín et al. 2010), of which examples can be found in domesticated crop plants (McKey et al. 2010). Linkage was still present when potential clone mates were excluded, which could be the result of a bottleneck in the elm populations (Flint-Garcia et al. 2003) caused by DED and habitat loss. In addition, the investigated elms seemed often highly related, which might suggest non-random mating. Non-random mating is likely to occur in small, fragmented woodland populations such as the Flemish elm populations. This can cause genetic drift and reduced genetic variation (Jump and Peñuelas 2006). Given the fact that biparental inbreeding is likely (e.g. Nielsen and Kjaer 2010), population differentiation might increase as a result of genetic drift and continuing losses of genotypes due to disease and additional loss of habitat. In addition, the spread of cultivars has probably influenced the remaining genetic resources of $U$. minor and $U$. glabra, potentially further altering the genetic variation. Steps taken to conserve the remaining elms in a field gene bank are therefore no wasted effort. The genetic markers and methodology used in this study will help in distinguishing clones, pure species, hybrids and cultivars among elms in the ex situ collection.

Since sexual reproduction appears to be rare in some locations in Flanders, especially in $U$. minor, energy put into the formation of F1 hybrids might be considered as wasted reproductive effort of the pure species, because F1 hybrids do not seem to succeed in creating F2 hybrids. The elm hybrids occupy, however, a great part of the ecological niches of both pure elm species in Flanders and therefore partly fulfil the ecological role of the parent taxa. Although the hybrids appear to be mainly 
human induced, the focus should be on conserving their ecological function. In turn, this will help maintain the structure of plant communities also containing (at one point) pure elms (Stronen and

3 Paquet 2013). Moreover, because of the abundance of clones and highly related individuals, the

4 residual gene pool, especially of the pure species, appears small and could become even smaller as 5 mentioned above. Introgression can be a source of genetic variation in the elm populations and may 6 promote adaptation (Grant and Grant 1994). Consequently, conserving the overall genetic variation is 7 warranted. Nonetheless, further research is required to determine whether elm hybrids in Flanders 8 have a competitive advantage over pure elm species, especially in regard to DED.

\section{Acknowledgements}

10 We would like to thank B. Maes for providing us with samples and useful information. Also many 11 thanks to Leen Verschaeve, Nancy Van Liefferinge, An Van Breusegem, David Halfmaerten and 12 Sabrina Neyrinck (INBO) for laboratory assistance and Stefaan Moreels (INBO) for his help in 13 collecting the samples and creating the Flemish elm gene bank. Finally, we thank the reviewers for 14 their insightful comments.

\section{Supplementary Material}

16 Fig. S1 Best maximum likelihood sibship assignment plot of the sibship structure for the unique 17 ramets of Flemish multilocus lineages of the U. minor-U. glabra complex obtained with Colony 18 v2.0.1.9. Above diagonal (black dots): full-sibs; below diagonal (grey dots): half-sibs. On both axes, 19 the location code of each individual is given

20 Data Archiving Statement

21 AFLP data: data will be deposited at Dryad 
2 Achard S (2012) Brainwaver: basic wavelet analysis of multivariate time series with a visualisation 3 and parametrisation using graph theory. R package version 1.6 edn.,

4 Aerts R, Berecha G, Gijbels P, Hundera K, Van Glabeke S, Vandepitte K, Muys B, Roldán-Ruiz I, 5 Honnay $O$ (2013) Genetic variation and risks of introgression in the wild Coffea arabica gene pool in 6 south-western Ethiopian montane rainforests. Evolutionary Applications 6:243-252. 7 doi:10.1111/j.1752-4571.2012.00285.x

8 Anderson EC (2008) Bayesian inference of species hybrids using multilocus dominant genetic markers. Philos T R Soc B 363:2841-2850

Anderson EC, Thompson EA (2002) A model-based method for identifying species hybrids using multilocus genetic data. Genetics 160:1217-1229

Anderson J, Churchill G, Autrique J, Tanksley S, Sorrells M (1993) Optimizing parental selection for genetic linkage maps. Genome 36:181-186 genetic diversity in clonal organisms: Low diversity or low resolution? Combining power and cost efficiency in selecting markers. J Hered 96:434-440

Arnold ML (1997) Natural hybridization and evolution. Oxford University Press, USA,

Arrigo N, Tuszynski JW, Ehrich D, Gerdes T, Alvarez N (2009) Evaluating the impact of scoring parameters on the structure of intra-specific genetic variation using RawGeno, an R package for automating AFLP scoring. BMC Bioinformatics 10:33. doi:10.1186/1471-2105-10-33

Benjamini $Y$, Hochberg $Y$ (1995) Controlling the false discovery rate - A practical and powerful approach to multiple testing. Journal of the Royal Statistical Society Series B-Methodological 57:289300

Bonin A, Bellemain E, Eidesen PB, Pompanon F, Brochmann C, Taberlet P (2004) How to track and assess genotyping errors in population genetics studies. Mol Ecol 13:3261-3273 Brasier CM (2001) Rapid evolution of introduced plant pathogens via interspecific hybridization. Bioscience 51:123-133. doi:10.1641/0006-3568(2001)051[0123:reoipp]2.0.co;2

Brundu G, Lupi R, Zapelli I, Fossati T, Patrignani G, Camarda I, Sala F, Castiglione S (2008) The origin of clonal diversity and structure of Populus alba in Sardinia: evidence from nuclear and plastid microsatellite markers. Ann Bot 102:997-1006. doi:10.1093/aob/mcn192 

Morus species (M. alba, M. rubra) that differ in abundance. Mol Ecol 14:3471-3483. doi:10.1111/j.1365-294X.2005.02670.x

Cogolludo-Agustin MA, Agundez D, Gil L (2000) Identification of native and hybrid elms in Spain using isozyme gene markers. Heredity 85:157-166. doi:10.1046/j.1365-2540.2000.00740.x

Collin E (2002) Strategies and guidelines for the conservation of the genetic resources of Ulmus spp. In: Turok J, Eriksson G., Russell K., Borelli S. (eds) Noble Hardwoods Network, Report of the fourth meeting, September 1999, Gmunden, Austria, and the fifth meeting, May 2001, Blessington, Ireland. International Plant Genetic Resources Institute, Rome, Italy, pp 50-67

Corander J, Marttinen P, Siren J, Tang J (2008) Enhanced Bayesian modelling in BAPS software for learning genetic structures of populations. BMC Bioinformatics 9:539. doi:10.1186/1471-2105-9-539 de Meeûs T, Balloux F (2004) Clonal reproduction and linkage disequilibrium in diploids: a simulation study. Infect, Genet Evol 4:345-351. doi:http://dx.doi.org/10.1016/j.meegid.2004.05.002

Douhovnikoff V, Dodd RS (2003) Intra-clonal variation and a similarity threshold for identification of clones: application to Salix exigua using AFLP molecular markers. Theor Appl Genet 106:1307-1315. doi:10.1007/s00122-003-1200-9

Edmands S (2007) Between a rock and a hard place: evaluating the relative risks of inbreeding and outbreeding for conservation and management. Mol Ecol 16:463-475. doi:10.1111/j.1365294X.2006.03148.x

Ellstrand NC, Schierenbeck KA (2000) Hybridization as a stimulus for the evolution of invasiveness in plants? Proceedings of the National Academy of Sciences 97:7043-7050. doi:10.1073/pnas.97.13.7043

Elwes HJ, Henry A, Henry A (1906) The trees of Great Britain \& Ireland / by Henry John Elwes and Augustine Henry, vol 7. Priv. print., Edinburgh. doi:10.5962/bhl.title.17123 Flint-Garcia SA, Thornsberry JM, S E, IV B (2003) Structure of linkage disequilibrium in plants. Annu Rev Plant Biol 54:357-374. doi:doi:10.1146/annurev.arplant.54.031902.134907

Forster ES, Heffner E (1954) Lucius Junius Moderatus Columella: On Agriculture II. Harvard University Press, Cambridge, Mass. Agrar-Sist Rec F 13:7-15 archipelago. Eur J Forest Res 131:347-354. doi:10.1007/s10342-011-0506-4 
1 Gil L, Fuentes-Utrilla P, Soto A, Cervera MT, Collada C (2004) English elm is a 2,000-year-old Roman

2 clone. Nature 431:1053-1053. doi:10.1038/4311053a

3 Gómez A, Carvalho GR (2000) Sex, parthenogenesis and genetic structure of rotifers: microsatellite 4 analysis of contemporary and resting egg bank populations. Mol Ecol 9:203-214. doi:10.1046/j.1365-

5 294x.2000.00849.x

6 Goodall-Copestake WP, Hollingsworth ML, Hollingsworth PM, Jenkins GI, Collin E (2005) Molecular

7 markers and ex situ conservation of the European elms (Ulmus spp.). Biol Conserv 122:537-546

8 Goodman SJ, Barton NH, Swanson G, Abernethy K, Pemberton JM (1999) Introgression through rare 9 hybridization: a genetic study of a hybrid zone between red and sika deer (genus Cervus) in Argyll, 10 Scotland. Genetics 152:355-371

11 Grant PR, Grant BR (1994) Phenotypic and genetic effects of hybridization in Darwin's finches. 12 Evolution 48:297-316

Halkett F, Simon J-C, Balloux F (2005) Tackling the population genetics of clonal and partially clonal organisms. Trends Ecol Evol 20:194-201. doi:http://dx.doi.org/10.1016/j.tree.2005.01.001

Haubold B, Hudson RR (2000) LIAN 3.0: detecting linkage disequilibrium in multilocus data. Bioinformatics 16:847-849. doi:10.1093/bioinformatics/16.9.847

Heybroek HM (1993) The Dutch elm breeding program. In: Sticklen MB, Sherald JL (eds) Dutch Elm Disease research. Springer New York, pp 16-25. doi:10.1007/978-1-4615-6872-8_3

Heybroek HM, Goudzwaard L, Kaljee H (2009) lep of Olm: karakterboom van de Lage Landen. KNNV Uitgeverij, Zeist, the Netherlands

Honnay O, Jacquemyn $\mathrm{H}$ (2008) A meta-analysis of the relation between mating system, growth form and genotypic diversity in clonal plant species. Evol Ecol 22:299-312. doi:10.1007/s10682-007-9202-8 Jones OR, Wang J (2009) COLONY: a program for parentage and sibship inference from multilocus genotype data. Mol Ecol Resour 10:551-555. doi:10.1111/j.1755-0998.2009.02787.x

Jump AS, Peñuelas J (2006) Genetic effects of chronic habitat fragmentation in a wind-pollinated tree. P Natl Acad Sci USA 103:8096-8100. doi:10.1073/pnas.0510127103

Kron P, Husband BC (2009) Hybridization and the reproductive pathways mediating gene flow between native Malus coronaria and domestic apple, M. domestica. Botany 87:864-874. doi:10.1139/B09-045

Laikre L, Schwartz MK, Waples RS, Ryman N, GeM WG (2010) Compromising genetic diversity in the wild: unmonitored large-scale release of plants and animals. Trends Ecol Evol 25:520-529 
1 Lambinon J, De Langhe J-E, Delvosalle L, Duvigneaud J (1998) Flora of Belgium, Luxembourg,

2 Northern France and neighboring areas (pteridophyta and spermatophyta). 3rd edn. National Botanic

3 Garden of Belgium, Meise

4 Lepais O, Petit RJ, Guichoux E, Lavabre JE, Alberto F, Kremer A, Gerber S (2009) Species relative

5 abundance and direction of introgression in oaks. Mol Ecol 18:2228-2242

6 Lynch M (1991) The genetic interpretation of inbreeding depression and outbreeding depression.

7 Evolution 45:622-629

8 Maes B (2006) Inheemse bomen en struiken in Nederland en Vlaanderen: herkenning, verspreiding,

9 geschiedenis en gebruik. Boom, Utrecht

10 Mariette S, Tavaud M, Arunyawat U, Capdeville G, Millan M, Salin F (2010) Population structure and

11 genetic bottleneck in sweet cherry estimated with SSRs and the gametophytic self-incompatibility

12 locus. BMC Genet 11:77

Martín JA, Witzell J, Blumenstein K, Rozpedowska E, Helander M, Sieber TN, Gil L (2013) Resistance to Dutch Elm Disease reduces presence of xylem endophytic fungi in elms (Ulmus spp.). PLoS ONE 8:e56987. doi:10.1371/journal.pone.0056987

Mayr E (1963) Animal species and evolution. Belknap Press of Harvard University Press, Harvard

McKey D, Elias M, Pujol B, Duputié A (2010) The evolutionary ecology of clonally propagated domesticated plants. New Phytol 186:318-332. doi:10.1111/j.1469-8137.2010.03210.x Meirmans PG, Van Tienderen PH (2004) GENOTYPE and GENODIVE: two programs for the analysis of genetic diversity of asexual organisms. Mol Ecol Notes 4:792-794

Mittempergher L, La Porta N (1991) Hybridization studies in the Eurasian species of elm (Ulmus spp.). Silvae Genet 40:237-243

Nei M (1978) Estimation of average heterozygosity and genetic distance from a small number of individuals. Genetics 89:583-590

Nielsen LR, Kjaer ED (2010) Gene flow and mating patterns in individuals of wych elm (Ulmus glabra) in forest and open land after the influence of Dutch elm disease. Conserv Genet 11:257-268 S, Manel S (2010) Tracking genes of ecological relevance using a genome scan in two independent regional population samples of Arabis alpina. Mol Ecol 19:2896-2907

Potts BM, Barbour RC, Hingston AB, Vaillancourt RE (2003) Turner Review No. 6. Genetic pollution of native eucalypt gene pools-identifying the risks. Aust $J$ Bot 51:1-25. doi:http://dx.doi.org/10.1071/BT02035 
1 R Development Core Team (2010) R: A language and environment for statistical computing. R

2 Foundation for Statistical Computing, Vienna, Austria

3 Rhymer JM, Simberloff D (1996) Estintction by hybridization and introgression. Annu Rev Ecol Syst

$4 \quad 27: 83-109$

$5 \quad$ Richens RH (1983) Elm. Cambridge University Press

6 Rieseberg LH (1997) Hybrid origins of plant species. Annu Rev Ecol Syst 28:359-389.

7 doi:10.2307/2952498

8 Santos-del-Blanco L, de-Lucas A, González-Martínez S, Sierra-de-Grado R, Hidalgo E (2013)

9 Extensive Clonal Assemblies in Populus alba and Populus $x$ canescens from the Iberian Peninsula.

10 Tree Genet Genom 9:499-510. doi:10.1007/s11295-012-0574-8

11 Smulders MJM, Beringen R, Volosyanchuk R, Vanden Broeck A, Schoot J, Arens P, Vosman B 12 (2008) Natural hybridisation between Populus nigra L. and P. x canadensis Moench. Hybrid offspring 13 competes for niches along the Rhine river in the Netherlands. Tree Genet Genom 4:663-675. 14 doi:10.1007/s11295-008-0141-5

Solla A, Bohnens J, Collin E, Diamandis S, Franke A, Gil L, Burón M, Santini A, Mittempergher L, Pinon J, Vanden Broeck A (2005) Screening European elms for resistance to Ophiostoma novo-ulmi. For Sci 51:134-141

Stronen AV, Paquet PC (2013) Perspectives on the conservation of wild hybrids. Biol Conserv 167:390-395. doi:http://dx.doi.org/10.1016/j.biocon.2013.09.004

Tibayrenc M, Kjellberg F, Arnaud J, Oury B, Brenière SF, Dardé ML, Ayala FJ (1991) Are eukaryotic microorganisms clonal or sexual? A population genetics vantage. Proceedings of the National Academy of Sciences 88:5129-5133. doi:10.1073/pnas.88.12.5129 Touw A (1963) Een voorlopig overzicht van de Nederlandse lepen. Jaarboek van de Nederlandse Dendrologische Vereniging 22:57-72. Townsend AM (1975) Crossability patterns and morphological variation among elm species and hybrids. Silvae Genet 24:18-23 Turelli M, Orr HA (2000) Dominance, epistasis and the genetics of postzygotic isolation. Genetics 154:1663-1679

Vähä J-P, Primmer CR (2006) Efficiency of model-based Bayesian methods for detecting hybrid individuals under different hybridization scenarios and with different numbers of loci. Mol Ecol 15:6372

32 Vallejo-Marín M, Dorken ME, Barrett SC (2010). The ecological and evolutionary consequences of 33 clonality for plant mating. Ann Rev Ecol Evol Syst 41:193-213 
1 van Dissel ED (1912) De storm van 30 sept.-1 Oct. 1911 in het Haagsche bosch. Staatsbosbeheer,

2 Utrecht

3 Vanden Broeck A, Cox K, Villar M (2012) Natural hybridization and potential seed set of sympatric

4 Populus nigra and Populus $x$ canadensis along the river IJzer in Flanders (Belgium). Plant Ecology

5 and Evolution 145:341-349. doi:10.5091/plecevo.2012.677

6 Vos P, Hogers R, Bleeker M, Reijans M, Vandelee T, Hornes M, Frijters A, Pot J, Peleman J, Kuiper

7 M, Zabeau M (1995) Aflp - a new technique for DNA-fingerprinting. Nucleic Acids Res 23:4407-4414

8 Wang J, Santure AW (2009) Parentage and sibship inference from multilocus genotype data under

9 polygamy. Genetics 181:1579-1594. doi:10.1534/genetics.108.100214

10 Webber JF (2004) Experimental studies on factors influencing the transmission of Dutch elm disease.

11 Inv Agrar-Sist Rec F 13:197-205

12 Wirtz P (1999) Mother species-father species: unidirectional hybridization in animals with female 13 choice. Anim Behav 58:1-12. doi:http://dx.doi.org/10.1006/anbe.1999.1144

14 Zalapa JE, Brunet J, Guries RP (2009) Patterns of hybridization and introgression between invasive 15 Ulmus pumila (Ulmaceae) and native U. rubra. Am J Bot 96:1116-1128. doi:10.3732/ajb.0800334 
Figures

Fig. 1 Map depicting the locations of the elm samples of Flanders (northern Belgium). The codes are given in Table 1.

Fig. 2 Posterior probabilities of genotype frequency classes given by NewHybrids (a) and admixture proportions given by BAPS (b) for Flemish elm samples and cultivars of U. glabra, U. minor or $U . x$ hollandica. The first half of the results is given above, the second half below. Samples are indicated with their location code (Table 1) or cultivar name (Table 2). Ramets of the same multilocus lineage (MLL) are indicated with the same number before the location code or a capital letter in case of a MLL found among locations. UM: U. minor; UG: U. glabra; F1: first generation hybrid; F2: offspring of F1 hybrids; BC to UM/UG: backcross to U. minor/U. glabra.

Fig. 3 Plot of number of loci versus genotypic richness (G:N) based consecutively on two highly polymorphic markers and sets of multiples of 16 markers with decreasing information content. For each set of loci, a range of G:N values (vertical lines), which were calculated using a different thresholds ( 0.90 to 0.99 Dice similarity). The line goes through mean $\mathrm{G}: \mathrm{N}$ values.

Fig. 4 Frequency distribution of pairwise Dice similarity index values with a maximum of 0.80 . 
Tables

Table 1 List of sampled locations of Ulmus minor, U. glabra, their hybrids and $U$. procera. N: number of sampled individuals; N AFLP: number of samples successfully analysed with AFLP; Nc: estimate of total number of individuals present on a location; Type LE: type of landscape element; UM: $U$. minor; UG: $U$. glabra; UH: U. x hollandica; UPR: U. procera; NA: not available.

\begin{tabular}{|c|c|c|c|c|c|c|c|c|c|}
\hline \multicolumn{10}{|c|}{ Dataset 1: Flemish samples (with species identification based on morphology) } \\
\hline BEBR & Belgium & Brugge (Sint-Pieters) & UM & 3.1728 & 51.2387 & 8 & 7 & 20 & Old hedge \\
\hline BEDI & Belgium & Dilbeek & UG & 4.2530 & 50.8536 & 2 & 2 & 10 & Forest \\
\hline BEDM1 & Belgium & Diksmuide & UM & NA & NA & 2 & 2 & NA & NA \\
\hline BEDM2 & Belgium & Diksmuide & UM & 2.9040 & 51.0095 & 4 & 4 & $5-10$ & Old hedge \\
\hline BEEG & Belgium & Heverlee & UG & 4.6662 & 50.8541 & 8 & 6 & $20-30$ & Forest \\
\hline BEEN & Belgium & Oudenaarde (Ename) & UM & 3.6593 & 50.8616 & 3 & 3 & $20-30$ & Wooded banks \\
\hline BEGE & Belgium & Geraardsbergen & UG (7), UH (1) & 3.9290 & 50.7700 & 8 & 8 & 20 & Forest \\
\hline BEHE & Belgium & Heusden & UM & 3.8159 & 51.0099 & 2 & 2 & $10-20$ & Old hedge \\
\hline $\mathrm{BEHO}$ & Belgium & Houthulst & UM & 2.8720 & 50.9770 & 4 & 4 & $10-20$ & Old hedge \\
\hline BELE & Belgium & Lemberge & UM & 3.7693 & 50.9788 & 5 & 5 & $10-20$ & Old hedge \\
\hline BEMA & Belgium & Maarkedal & UM (1), UG (5), UH (1) & 3.6520 & 50.8247 & 7 & 7 & $10-15$ & Wooded bank \\
\hline BEME1 & Belgium & Merelbeke & UM (5), UH (1) & 3.7198 & 50.9519 & 6 & 6 & 10 & Forest \\
\hline BEME2 & Belgium & Merelbeke & $\mathrm{UH}$ & 3.7508 & 50.9739 & 3 & 3 & 10 & Forest \\
\hline BEOO & Belgium & Oosterzele & UM & 3.8065 & 50.9350 & 1 & 1 & 10 & Forest edge \\
\hline BERI & Belgium & Riemst & UM (4), UG (29), UH (3) & 5.6857 & 50.8058 & 38 & 36 & $50-100$ & Forest \\
\hline BESC & Belgium & Schorisse & UM (1), UG (4), UH (2) & 3.7065 & 50.8028 & 7 & 7 & $20-30$ & Forest, wooded bank \\
\hline BESP & Belgium & Sint-Pieters-Kapelle (Herne) & NA & 3.9795 & 50.6930 & 2 & 2 & NA & NA \\
\hline BETO $^{a}$ & Belgium & Tongeren & UG & 5.4908 & 50.8035 & 1 & 1 & NA & Private park \\
\hline \multicolumn{10}{|c|}{ Dataset 2: reference samples } \\
\hline Location & Country & City & Species & Lon & Lat & $\mathrm{N}$ & N AFLP & & \\
\hline FRAM $^{b}$ & France & Amplier & UM & 2.4010 & 50.1352 & 1 & 1 & & \\
\hline FRAR $^{\mathrm{b}}$ & France & Argentan & UM & -0.0187 & 48.7402 & 1 & 1 & & \\
\hline FRAU & France & Aunay & UM & 0.6307 & 49.0205 & 2 & 2 & & \\
\hline
\end{tabular}




\begin{tabular}{|c|c|c|c|}
\hline FRBB $^{b}$ & France & Bourg-Blanc & UM \\
\hline FRBL & France & Blismes & UM \\
\hline FRCB & France & La Chapelle-Bâton & UM \\
\hline $\mathrm{FRCM}^{\mathrm{b}}$ & France & Saint-Martin-de-Ré & UM \\
\hline $\mathrm{FRCU}^{\mathrm{b}}$ & France & Cucq & UM \\
\hline FRGO $^{b}$ & France & Godewaersvelde & UM \\
\hline FRGS $^{b}$ & France & Grande-Synthe & UM \\
\hline FRIL $^{b}$ & France & Illkirch-Graffenstaden & UM \\
\hline FRLR & France & Le Rheu & UM \\
\hline FRLV & France & Le Vey & UM \\
\hline FRLW $^{b}$ & France & La-Wantzenau & UM \\
\hline FRMA $^{b}$ & France & Magnicourt-en-Comte & UM \\
\hline FRME $^{\mathrm{b}}$ & France & Meteren & UM \\
\hline $\mathrm{FRMQ}^{\mathrm{b}}$ & France & Mecquignies & UM \\
\hline FROS $^{b}$ & France & Ostwald & UM \\
\hline FRSP & France & Saint-Pé-de-Bigorre & UG \\
\hline FRST $^{\mathrm{b}}$ & France & Strasbourg & UM \\
\hline GEGO $1^{\mathrm{C}}$ & Germany & Göttingen & UG \\
\hline $\mathrm{GEGO}^{\mathrm{C}}$ & Germany & Göttingen & UM \\
\hline GEKA & Germany & Pfalz & UPR \\
\hline GELD $^{c}$ & Germany & Lüchow-Dannenberg & UM \\
\hline GRIR $^{d}$ & Greece & Iraklion & UM \\
\hline GRTH $^{d}$ & Greece & Thessaloniki & UM \\
\hline ITBO $^{e}$ & Italy & Bolzano & UG \\
\hline $\operatorname{ITCA}^{\mathrm{e}}$ & Italy & Catanzaro & UM \\
\hline ITFV & Italy & Fiume Veneto & UM \\
\hline ITLA $^{e}$ & Italy & Latina & UM \\
\hline ITMO $^{e}$ & Italy & Monfalcone & UM \\
\hline $\mathrm{ITNI}^{\mathrm{e}}$ & Italy & Nimis & UM \\
\hline ITSE ${ }^{\mathrm{e}}$ & Italy & Sesto Al Reghena & UM \\
\hline ITTA $^{e}$ & Italy & Tamai & UM \\
\hline
\end{tabular}

$\begin{array}{llll}-4.5017 & 48.5005 & 1 & 1 \\ 3.8202 & 47.1315 & 1 & 1 \\ 0.3297 & 46.4746 & 3 & 3 \\ -1.3593 & 46.2027 & 1 & 1 \\ 1.6207 & 50.4742 & 1 & 1 \\ 2.6380 & 50.7898 & 1 & 1 \\ 2.2897 & 51.0087 & 1 & 1 \\ 7.7185 & 48.5243 & 1 & 1 \\ 1.7954 & 48.1011 & 2 & 2 \\ 0.4701 & 48.9175 & 5 & 5 \\ 7.8222 & 48.6575 & 1 & 1 \\ 2.4877 & 50.4018 & 1 & 1 \\ 2.6880 & 50.7383 & 2 & 2 \\ 3.7890 & 50.2738 & 1 & 1 \\ 7.7058 & 48.5403 & 1 & 1 \\ 0.1552 & 43.0737 & 3 & 2 \\ 7.7537 & 48.5845 & 1 & 1 \\ 9.1500 & 51.3333 & 3 & 2 \\ 9.9557 & 51.6502 & 1 & 1 \\ \text { NA } & \mathrm{NA} & 1 & 1 \\ 10.8833 & 53.2667 & 3 & 3 \\ 24.8062 & 35.3878 & 1 & 1 \\ 23.7340 & 40.7523 & 1 & 1 \\ 11.1167 & 46.6167 & 1 & 1 \\ 16.7500 & 38.8833 & 1 & 1 \\ 12.6833 & 45.9167 & 1 & 1 \\ 13.0000 & 41.4667 & 1 & 1 \\ 13.5333 & 45.8000 & 1 & 1 \\ 13.2500 & 46.2167 & 1 & 1 \\ 12.7833 & 45.8667 & 1 & 1 \\ 12.5667 & 45.9333 & 2 & 2\end{array}$


ITTR

Italy

Trieste

UM

13.7000

45.7167

1

Samples from the RESGEN collection provided by the following institutes:

${ }^{a}$ Research Institute for Nature and Forest (INBO), Belgium

${ }^{\mathrm{b}}$ Institut national de recherche en sciences et technologies pour l'environnement et l'agriculture (Irstea), France

${ }^{\mathrm{c}}$ Niedersächsische Forstliche Versuchsanstalt (NFV), Germany

${ }^{d}$ National Agricultural Research Foundation (NAGREF), Greece

${ }^{\text {e }}$ Consiglio Nazionale delle Ricerche (CNR), Italy 
Table 2 List of sampled elm cultivars included in the study (i.e. dataset 3).

\begin{tabular}{|c|c|}
\hline Cultivars & Parents/species \\
\hline Lobel (3 ramets) & $\begin{array}{l}\text { clone } 202 \text { (U. glabra 'Exoniensis' × U. wallichiana) } \times \\
\text { clone } 336 \text { ('Bea Schwarz' a , selfed) }\end{array}$ \\
\hline Clusius & $\begin{array}{l}\text { clone } 202 \text { (U. glabra 'Exoniensis' × U. wallichiana) x } \\
\text { clone } 336 \text { ('Bea Schwarz' a , selfed) }\end{array}$ \\
\hline Sapporo Autumn Gold & U. pumila x U. japonica \\
\hline $73 P$ & $\begin{array}{l}\text { U. pumila (mother tree of 'Sapporo Autumn Gold') } \times \\
\text { ? (open pollinated) }\end{array}$ \\
\hline $2 \mathrm{P}$ & U. japonica \\
\hline Klemmer & $\begin{array}{l}\text { U. } x \text { hollandica } \\
\text { or U. minor }\end{array}$ \\
\hline Dodoens & $\begin{array}{l}\text { Selfed seedling of clone } 202 \text { (U. glabra 'Exoniensis } \\
\times \text { U. wallichiana) }\end{array}$ \\
\hline Groeneveld & $\begin{array}{l}\text { clone } 49(U . \text { glabra or } U . \times \text { hollandica }) \times \text { clone } 1(U \\
\text { minor })\end{array}$ \\
\hline Commelin & U. x hollandica 'Vegeta' x clone 1 (U. minor) \\
\hline Plantyn (2 ramets) & $\begin{array}{l}\text { Clone } 202(U . \text { glabra 'Exoniensis' } \times \text { U. wallichiana) } \\
\text { x clone } 302(U . \text { minor '1' × U. minor '28') }\end{array}$ \\
\hline Christine Buisman & U. minor \\
\hline Vegeta & U. x hollandica \\
\hline Major & U. x hollandica \\
\hline Belgica & U. x hollandica \\
\hline Horizontalis & U. glabra \\
\hline Dampieri & $\begin{array}{l}\text { U. x hollandica } \\
\text { or U. minor }\end{array}$ \\
\hline Den Haag & U. pumila x U. x hollandica 'Belgica' \\
\hline Columella & Probably selfed seedling of Plantyn \\
\hline Sarniensis & U. minor \\
\hline
\end{tabular}

a 'Bea Schwarz' is an U. minor or U. $x$ hollandica. 
Table 3 Information on the variation of the AFLP loci. N: number of samples; NPL: number of polymorphic loci; BF: mean band frequency; PIC: mean polymorphic information content; $\mathrm{NPL}_{0.05-0.95}$ : number of polymorphic loci with a band frequency between 0.05 and 0.95 ; $\mathrm{PIC}_{0.05-0.95}$ : mean polymorphic information content of loci with a band frequency between 0.05 and 0.95 .

\begin{tabular}{|c|c|c|c|c|c|c|}
\hline Primer combinations & $\mathrm{N}^{\mathrm{a}}$ & $\overline{N P L}$ & $\begin{array}{l}\text { BF } \\
\text { (st. dev.) }\end{array}$ & $\begin{array}{l}\text { PIC } \\
\text { (st. dev.) }\end{array}$ & $\mathrm{NPL}_{0.05-0.95}$ & $\begin{array}{l}\mathrm{PIC}_{0.05-0.95} \\
\text { (st. dev.) }\end{array}$ \\
\hline EcoRI-AGC/Msel-CTG & 174 & 169 & $0.35(0.35)$ & $0.21(0.17)$ & 110 & $0.30(0.14)$ \\
\hline EcoRI-ACC/Msel-CTG & 174 & 216 & $0.26(0.35)$ & $0.15(0.15)$ & 100 & $0.27(0.14)$ \\
\hline Species group & $\mathrm{N}^{\mathrm{a}}$ & NPL & $\begin{array}{l}\text { BF } \\
\text { (st. dev.) }\end{array}$ & $\begin{array}{l}\text { PIC } \\
\text { (st. dev.) }\end{array}$ & $\mathrm{NPL}_{0.05-0.95}$ & $\begin{array}{l}\mathrm{PIC}_{0.05-0.95} \\
\text { (st. dev.) }\end{array}$ \\
\hline Ulmus minor & 77 & 314 & $0.31(0.36)$ & $0.17(0.14)$ & 187 & $0.26(0.13)$ \\
\hline Ulmus glabra & 34 & 222 & $0.35(0.35)$ & $0.22(0.15)$ & 163 & $0.27(0.14)$ \\
\hline $\begin{array}{l}\text { Hybrids } U . \text { minor }-U \text {. } \\
\text { glabra }\end{array}$ & 53 & 249 & $0.35(0.36)$ & $0.20(0.16)$ & 145 & $0.30(0.13)$ \\
\hline remaining samples & 10 & 248 & $0.39(0.27)$ & $0.33(0.12)$ & 248 & $0.33(0.12)$ \\
\hline
\end{tabular}

${ }^{a}$ Excl. duplicate ramets of Lobel and Plantyn. 
BEBR

$$
\text { BEDM } 1 \text { BEDM2 }
$$

BEHO

$$
\text { BESC BESPE }
$$$$
\text { BEDI }
$$$$
\text { BEEG }
$$

BETO

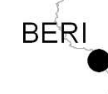
$\begin{array}{lll} & & \\ 0 & 12.5 & 25\end{array}$ 


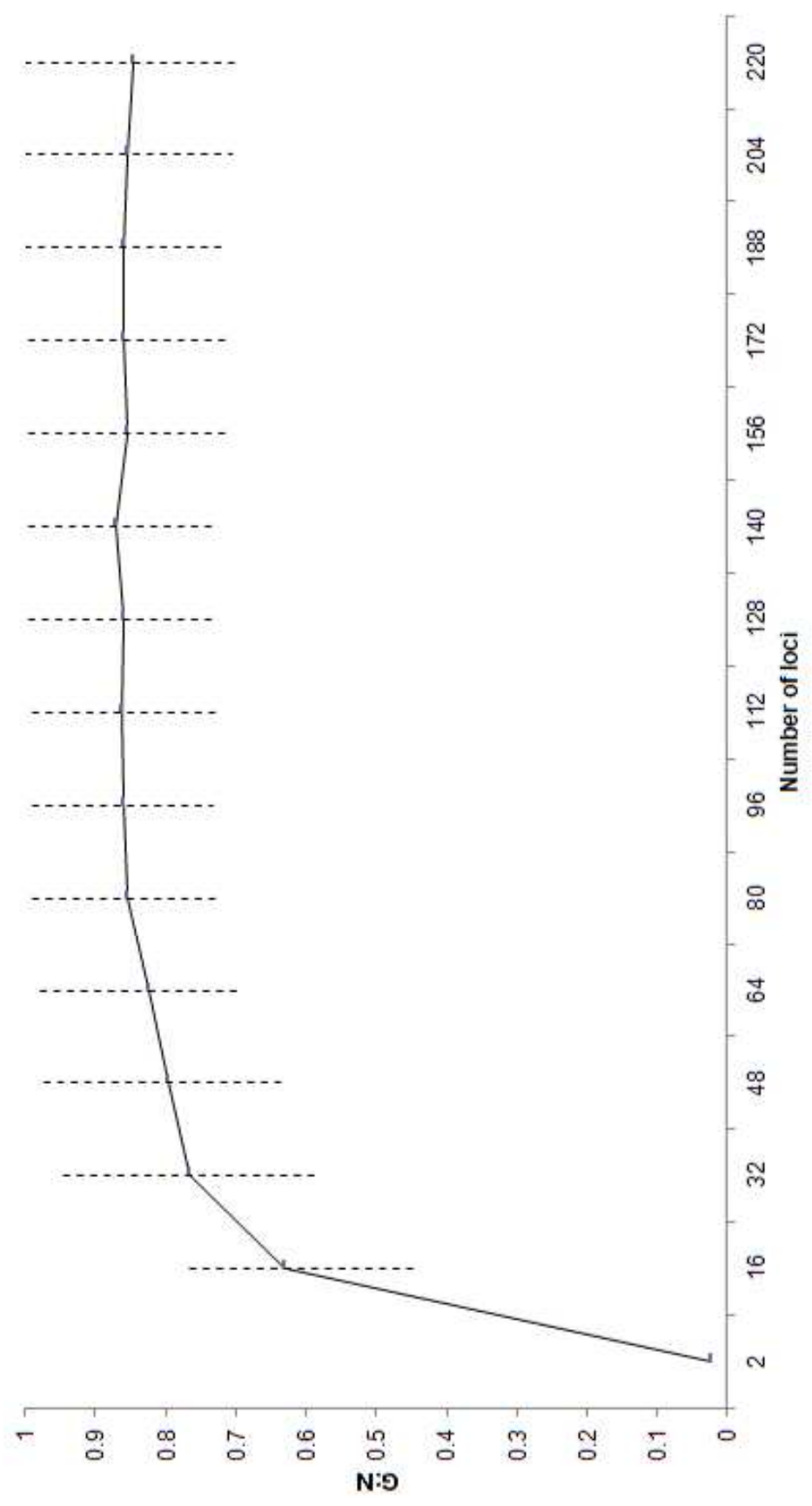




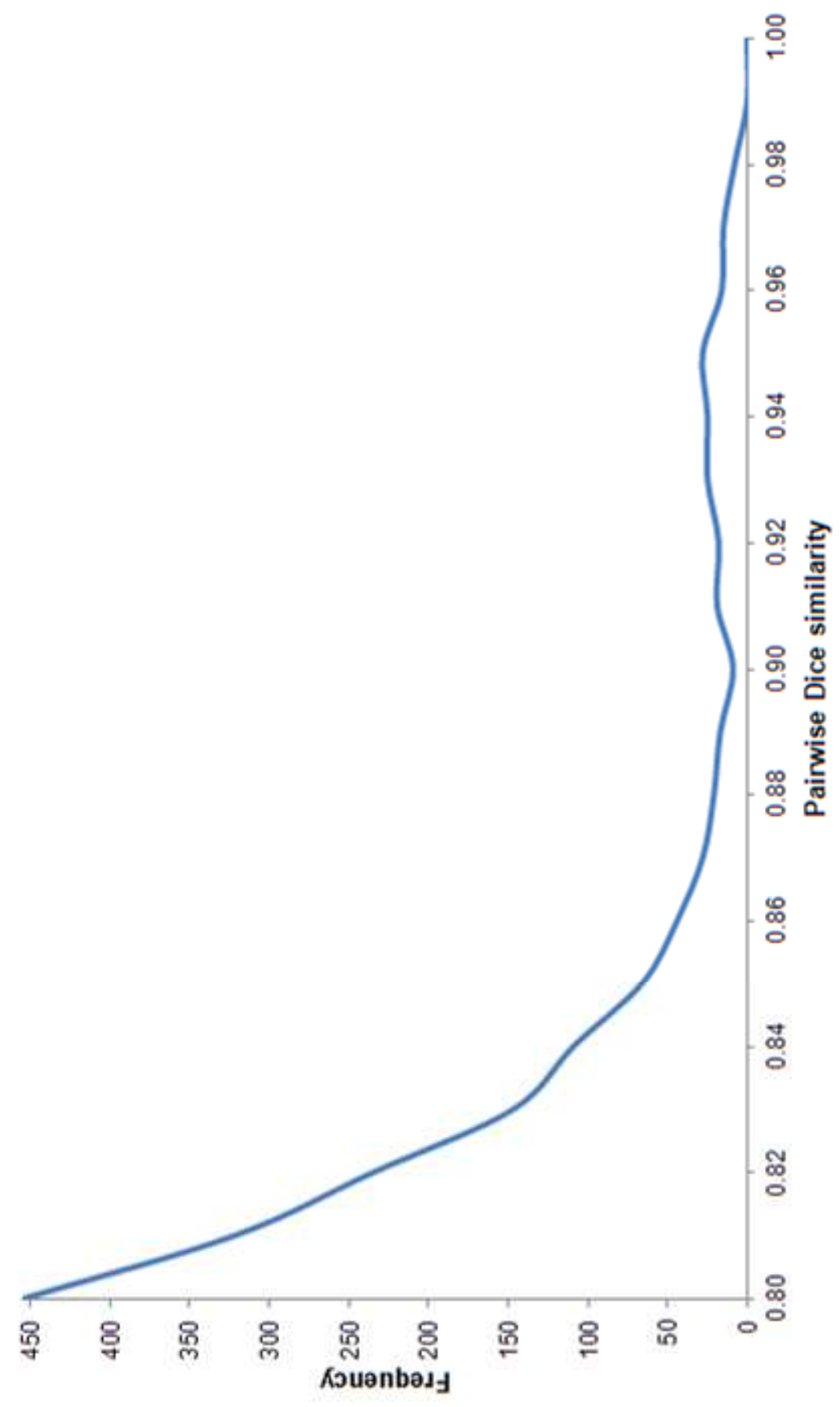

